\title{
Látrányi Puszta Természetvédelmi Terület díszbogarai (Coleoptera: Buprestidae)
}

\author{
MUSKOVITS JózSEF
}

H-1113 Budapest, Tardoskedd u. 9., Hungary

Muskovits J.: Jewel beetles (Coleoptera: Buprestidae) from the Látrányi Puszta Nature Conservation Area (Somogy county, Hungary).

Abstract: A list of 20 jewel beetle species known to occur in a nature reserve at Látrány (Somogy county, Hungary) is given.

Key words: Bupestridae, Hungary

\section{Fajok jegyzéke}

Az irodalomban Látrányra vonatkozó díszbogár-adat Somogy fauna katalógusa kivételével nem jelent meg. A fentemlített katalógusban Látrányból csak 3 faj található, ami nem nagyon meglepő, hiszen a vizsgált területen a gyüjtések alig néhány éve kezdődtek meg. A jelen összeállításban közzétett fajok jegyéke Rozner György, Rozner István, Szalóki Dezső, Podlussány Attila és Merkl Ottó által gyütött példányok alapján készült. A példányokat a szerző határozta meg. A gyüjtött anyag kisebb része a Magyar Természettudományi Múzeum (Budapest), nagyobbik része Rozner György (Kisberény), Rozner István (Budapest) és Szalóki Dezső (Budapest) gyüjteményében van elhelyezve. A gyüjtő neve után zárójelben a gyüjtött példányok száma szerepel, amennyiben egynél több példány került elö. A területről jelenleg kimutatott 20 díszbogárfaj a Magyarországról ismert fajoknak kereken az egyhatoda. Védett faj nem került elő.

Sphenoptera parvula (Fabricius, 1798) Látrány: Kolláti-erdő, 1999.05.22.-06.24. Rozner Gy. (talajcsapda).

Phaenops cyanea (Fabricius, 1775) - Látrány, 1998.06.22. Rozner Gy.; 2001.05.03. Rozner Gy. (5),; 2001.07.05. Merkl O.

Anthaxia fulgurans (Schrank, 1789) - Látrány: Birkás-legelö, 2002.04.26. Rozner Gy.; 2000.04.29. Rozner Gy.

Anthaxia nitidula nitidula (Linnaeus, 1758) Látrány: Birkás-legelö, 2002.04.29. Rozner Gy (2); 2000.05.13. Rozner Gy. (2) - Látrány: Kolláti-legelö, 2001.06.03. Rozner I.

Anthaxia semicuprea Küster, 1851 - Látrány: Birkás-legelö, 2002.04.26. Podlussány A.

Anthaxia (Melanthaxia) quadripunctata (Linnacus, 1758) - Látrány: Birkás-legelő, 2002.04.26. Podlussány A.
Coraebus elatus (Fabricius, 1787) - Látrány: Birkás-legelő, 2001.06.26. Rozner I.; 2001.07.05. Merkl O.

Agrilus angustulus (Illiger, 1803) - Látrány: Birkás-legelö, 2001.06.14. Rozner Gy. Agrilus convexicollis Redtenbacher, 1849 -

Látrány: Birkás-legelő, 2000.05.13. Rozner Gy. Agrilus cuprescens Ménétries, 1832 - Látrány: Birkás-legelö, 2002.06.30. Merkl O. Agrilus graminis Laporte et Gory, 1839 Látrány, 2001.07.03. Rozner Gy. Agrilus hyperici (Creutzer, 1799) - Látrány, 1998.06.22. Rozner Gy. Agrilus olivicolor Kiesenwetter 1857 - Látrány: Birkás-legelö, 2001.06.14. Rozner Gy. Agrilus roscidus Kiesenwetter, 1857 - Látrány: Birkás-legelő, 2001.06.14. Rozner Gy. (6) 
Agrilus viridis (Linnaeus, 1758) - Látrány, 2001.06.26. Rozner Gy. - Látrány: Kolláti-legelö, 1999.07.12. Rozner Gy; 2001.05.13. Rozner Gy (5)

Cylindromorphus filum (Gyllenhal, 1817) Látrány, 1998.06.22. Rozner Gy. - Látrány: Akasztódomb, 2000.06.11. Szalóki D. (3) - Látrány: Birkáslegelö, 2000.05.13. Rozner Gy.; 2001.06.06. Rozner Gy; 2001.07.19. Rozner Gy.

Aphanisticus elongatus Villa, 1835 - Látrány: Birkás-legelö, 2001.0́4.26. Rozner I.

Aphanisticus pusillus (Olivier, 1790) - Látrány: Akasztó-domb, 2000.06.11. Szalóki D. - Látrány: Tetves-patak, 2001.04.25. Rozner Gy.
Trachys minutus (Linnaeus, 1758) - Látrány, 1998.08.22. Rozner Gy.; 1999.04.30. Rozner Gy.; 2001.04.24. Rozner Gy. (5) - Látrány: Akasztódomb, 2000.06.11. Szalóki D. - Látrány: Birkás-legelö, 1997.06.18. Rozner I. (6); 1998.04.24. Rozner Gy. (5); 2000.04.20. Rozner Gy. (8); 2001.04.26. Rozner I. (6) Podlussány A. (3); 2000.05.13. Rozner Gy. (2); 2002.05.04. Merkl O. - Látrány: Kolláti-legelö, 1999.07.12. Rozner Gy.; 2000.05.13. Rozner Gy. (2); 2001.04.26. Rozner I. (3); 2001.10.05. Podlussány A.

Trachys scrobiculatus Kiesenwetter, 1857 Látrány: Birkás-legelő, 2000.04.20. Rozner Gy.

\section{Köszönetnyilvánítás}

Köszönetemet fejezem ki dr. Merkl Ottónak, Rozner Györgynek, Rozner Istvánnak és Szalóki Dezsőnek, hogy a gyüjteményükben található díszbogarak adatait felhasználhattam.

\section{Irodalom}

Muskovits J. 2001: Somogy megye díszbogarai (Coleoptera: Buprestidae). In Ábrahám L. ed.: Somogy fauna katalógusa? Natura Somogyiensis 3., Kaposvár, 2001: 169-178 pp. 